\title{
Citizenship and Belonging: The Case of the Italian Vote Abroad
}

\author{
David Aliano \\ College of Mount Saint Vincent
}

The ease in which people are able to travel and communicate with one another across national boundaries is challenging the way in which we identify ourselves and define our place in the world. In an increasingly globalized world the very concept of a national identity is itself being redefined as multiple identities and dual citizenships have become more common than ever. This process of global interconnectedness has progressed so rapidly in the past few years that many are beginning to question how we define national models. The European Union, NAFTA, MERCOSUR, multi-national corporate affiliations, and virtual communities over the internet are all fast creating new collective forms of identity filling a role traditionally associated with the nation-state. These new realities test the limits of traditional citizenship models and challenge us to rethink national identities that transcend borders.

In December 2001 the Italian Parliament passed a law granting Italian citizens living abroad the right to not only vote in Italian elections but to also elect their own 
specially designated representatives to the Italian Parliament. Many of these new voters were second and third generation children of emigrants who had only recently attained their Italian citizenship. These new citizens played a decisive role in their ancestral homeland's political process and in so doing provoked no small amount of debate over extraterritorial citizenship. This article uses the example of the recently changed Italian law to explore the complex ways in which citizenship and national identities are being redefined. I focus particularly on the relationship between citizenship laws and the broader issue of being identified with and accepted as a member of a nation. Placing the current Italian case in a comparative context, I argue that Italy's new law and the complex problems which have arisen as a result serve as an important model for other nations to examine. It is a model which is especially relevant for many nations in Latin America and Asia whose current migration patterns share a number of similarities with Italy's historical migration experience.

\section{Towards a Transnational Understanding of National Identity}

For many the possibility of dual citizenship and voting from abroad is a sign that globalization is rapidly undermining the traditionally defined nation-state. In this context, the new Italian law could be viewed as a harbinger of a new transnational world in which individuals across borders would share a similar set of rights in the past reserved for citizens living within a given territorial state.

In recent years scholars have begun to adapt transnational theoretical frameworks which reflect these changing global realities. Within the field of Italian migration studies, the historian Donna R. Gabaccia highlighted the limits of national frameworks for understanding an historical phenomenon which by its nature is transnational. In her article, "Is Everywhere Nowhere? Nomads, Nations, and the Immigrant paradigm of United States His- 
tory" (1999), Gabaccia calls on scholars to move beyond "the tyranny of the national in writing history," by studying migration and national projects from a transnational perspective. ${ }^{1}$ Applying this perspective to the question of citizenship challenges us to re-think our very understanding of a concept inextricably linked to the nation-state model of national identity.

In assessing the possibilities presented by a new transnational model of citizenship, Irene Bloemraad, in her article, "Who Claims Dual Citizenship? The Limits of Postnationalism, the Possibilities of Transnationalism, and the Persistence of Traditional Citizenship" (2004), recognizes that new laws allowing for dual citizenship normalizes the transnational lives of many migrants. Relying on an empirical analysis of Canadian census data, she argues however that these new trends actually appear to reinforce, rather than undermine, the traditionally defined nation-state. This is the case because migrants are still granted their citizenship status from nation-states and are more likely to become naturalized in their new nation if they can also maintain their original citizenship. ${ }^{2}$

Rainer Bauböck in his article, "Expansive Citizenship-Voting Beyond Territory and Membership" (2005) in turn identifies voting rights for non-citizen residents as the "complementary phenomenon" to voting rights for non-resident citizens. Bauböck maps out four contrasting arguments for and against both cases. For Bauböck, the ideal principle for resolving the question of resident and expatriate citizenship is "stakeholdership," which he explains makes "an individual's fundamental rights dependent on protection by a particular polity and ties the individual's well-being to the common good of the polity." 3 This new conceptualization would encompass immigrant residence as well as expatriates with continued ties to the country. Individuals who had never resided in the country would however be excluded. This solution addresses the new realities of overlapping citizenship in a new globalized world, but continues to place impor- 
tance on the role of residence in defining an individual's relationship to the nation-state.

Many of the theoretical issues raised by this recent scholarship on transnational citizenship are illustrated by the case of the Italian vote abroad. This article examines how one nation in particular has grappled with the transnational dimensions of its national identity both in the past as well as in the present in order to illustrate the fascinating problems and possibilities posed by extraterritorial citizenship. The Italian government by granting voting rights to the children of Italian emigrants recognized the value of a citizen's extra-territorial links to the nation, and in so doing challenges us as scholars to rethink what it means to belong to a nation.

\section{Italy and Italians Living Abroad}

The question extraterritorial citizenship and the rights and obligations which it entails is not a new one for the Italian State. For over a century the Italian government has played an active role in cultivating transnational relationships with its emigrants. The recent Italian electoral law is in fact a logical culmination of a policy long in the making. It is therefore essential to study the historical contours of the debate over Italian citizenship abroad in order to understand and evaluate the current law and its implications. These historical experiences also highlight the limitations and contradictions inherent in the implementation of national policies across territorial borders.

Between 1875 and 1975 over 25 million Italians emigrated out of Italy. Emigrating primarily out of socio-economic necessity, many Italians traveled back and forth between Italy and their new adopted homes, influencing in the process both their new nation as well as Italy. Through their investments and remittances, consumption and cultural assimilations they created their own unique transnational identity. As Gabaccia in her groundbreaking study, Italy's Many Diasporas (2000) explained, “Migration made transnationalism a normal dimension of life 
for many, perhaps even most, working class families in Italy in the nineteenth and twentieth centuries. Family discipline, economic security, reproduction, inheritance, romance, and dreams transcended national boundaries and bridged continents." 4 With its citizens already leading transnational lives by the late-nineteenth century, the Italian government responded early to the new realities posed by migration.

More active than most governments of the time, the liberal regime in Italy (1870-1922) attempted to maintain formal connections with its emigrant communities abroad by investing state resources in services for its emigrants. According to the historian Mark I. Choate in his work, Emigrant Nation, The Making of Italy Abroad (2008) the liberal regime's active involvement with its emigrant population represented a conscious effort to "nationalize its emigration by intervening transnationally, levering diplomatic resources to influence international travel, the dissemination of media, transnational religious activity, and ethnic economic activity abroad to achieve specific national benefits." 5 If viewed in this context, liberal Italy's overtures towards its citizens abroad was as much as reflection of a traditional national agenda as it is an innovative response to a transnational reality.

To maintain influence over its transnational citizens, the liberal state created a special commission to deal with emigrant affairs. The Commissariato Generale dell'Emigrazione was founded in 1901 with the task of providing services to Italian emigrants abroad. The Commissariato compiled vital statistics about the various countries of immigration. It published numerous manuals and handbooks for emigrants. These works provided travel information, compared the labor markets of various countries provided data on salaries and job opportunities abroad as well as collected foreign legal codes relevant to emigrant laborers. The main organ of the Commissariato was the monthly Bollettino dell'Emigrazione, which provided readers with reports and telegrams from the 
various Italian embassies, legal codes, travel advisories, parliamentary debate, and statistical information on Italian migration as well as feature length articles on important international political developments. ${ }^{6}$

During this period, Italy's transnational claims over its citizens abroad created diplomatic conflicts in an age prior to dual citizenship. Based on Jus Sanguinis, the ethnic blood-based concept of citizenship, Italians living abroad and their children maintained their legal rights, protections and obligations to the State even while abroad. Many nations however followed the principle of Jus Solis, citizenship based on residence and place of birth, and accordingly new residents were obligated to fulfill their duties as citizens of their new nation and were offered the same protections as other citizens in the national territory. International law and the national sovereignty ensured that the receiving nations had the upper-hand in responding to Italy's competing claims over its citizens abroad.

Two specific issues highlighted the limitations of applying a citizenship law outside the nation territory: the obligation of military service and the extra-territorial legal protections of citizens residing abroad. In Brazil these issues were especially problematic given its policy of automatic naturalization after six months of continuous residence. Italian consular officials were therefore limited in their ability to protect its emigrants from Brazilian laws which ran contrary to their own. ${ }^{7}$ Further complicating the issue of contested citizenship issue was the fact that the vast majority of Italian emigrants at the time expressed little interest in passing on their Italian citizenship to their children, who by right of birth were automatically granted an American citizenship. This was especially the case in the United States. For example, for the 1907 calendar year in the City of New York, a city with millions of Italian immigrants and their children, only three births were reported to the Italian Consulate so that their children's Italian citizenship would be rec- 
ognized. ${ }^{8}$ Without the possibility of dual citizenship, liberal Italy's extraterritorial claims on its emigrants was no match for the allure of attaining citizenship in the land in which emigrants lived, worked, and raised their families.

During the fascist period (1922-1945), Mussolini promoted a more ambitious nationalist agenda which attempted to reclaim Italian emigrants for Italy's national project. In the early 1920s this meant promoting emigration as a form of Italian national expansion. ${ }^{9}$ In 1923 Mussolini placed the Commissariato Generale dell'Emigrazione under the direct authority of the Ministry of Foreign Affairs. Such a move demonstrated the political and diplomatic importance of emigration at the time. With emigrants viewed as potential political capital for the regime, close and more direct coordination between the government through its embassies and consular services was essential. ${ }^{10}$

In 1924 Mussolini convened the first International Conference on Emigration and Immigration in Rome. The stated goal of the conference was to establish an international accord to regulate the flow of immigration and standardize legal protections and services for immigrants. Mussolini's ulterior motive, soon apparent once the conference began, was in fact to attain formal international recognition for Italy's legal claims over its emigrant citizens abroad. ${ }^{11}$

The Italian delegation at the conference pushed an ambitious emigration agenda: insisting that emigrants and their children, wherever they may be, legally remained subjects of their nation of origin. They attempted and failed to pass proposals which would have given its consular officials the power to intervene in domestic trials involving emigrant nationals, would have required emigrants to serve in their birth country's military while exempting them from military service in their new nations, and finally would have allowed government-sponsored 'patriotic organizations' to operate unhindered in other nation-states. ${ }^{12}$ Taken together, these proposals re- 
defined traditional notions of citizenship by giving priority to the emigrants' nation of origin over their nation of residence and would have done nothing less than deterritorialize the nation-state.

Seen as clear violations of their national sovereignty, it is easy to understand why most nations rejected these proposals. The delegations from all of the nations in the Americas rejected the Italian definition of citizenship. They argued that once emigrants chose to live and have children in a new nation, they became citizens of that nation. No longer obligated to serve their former nation, nor under its protection, these immigrants had the same rights and duties of all other citizens living in their adopted nation. ${ }^{13}$ With two fundamentally different and irreconcilable definitions of citizenship on the table, any agreement between Italy and the nations which received its emigrants was unlikely. In the end few resolutions of substance were passed at the conference. Only those resolutions which affirmed immigrant laborers' human rights were approved, while those that attempted to promote Mussolini's expansive citizenship agenda were not. ${ }^{14}$

The social realities of emigration along with international resistance made it readily apparent to Mussolini that his expansive stance on emigration was no longer tenable. In 1927 the regime declared that emigration was now a loss to the nation, it was no longer the expansion of Italy outside its borders but instead "de-nationalization." 15 Although the Italian foreign minister, Dino Grandi, maintained that the government through his ministry would continue to promote Italian identity among Italian citizens living abroad, emigration as a national policy was now a dead issue. He declared that "From now on there will no longer be emigrants, only Italians abroad"16

Grandi's reference to "Italians abroad" provided a new impetus to the regime's efforts at promoting Italian citizenship outside the nation state. In fact, with the issue of Italian identity abroad no longer linked to the 
debate over emigration, the regime's outlook was broadened rather than diminished. With the mass migration of Italians now over, the possibility remained of establishing a new relationship between Italian collectivities abroad and fascist Italy. Preserving Italian citizenship abroad and winning the support of Italian collectivities for fascism's international policies characterized the fascist regime's new interest in its emigrants. Piero Parini the new Director of Italians Abroad, demonstrated the possibilities created by the fascist regime's new approach. Separating Italian identity abroad from the emigration debate, he explained that, "If there is a sector in which fascism has radically renovated a mentality and consciousness, it is undoubtedly that of Italian-ness outside of its borders... across the world there are eight million Italians; a nation outside of the Nation."17 These lines suggest that the regime while rejecting emigration continued to encourage and promote the idea of a new Italian citizenry outside of the borders of the nation-state.

During the 1930s Italian fascists had hoped that by promoting Italian identity in the Diaspora they would be able to garner support abroad for the fascist regime and its political agenda, in this they failed abjectly. They did however succeed in provoking a debate at home and abroad over the question of transnational citizenship and the potential political roles that citizens living abroad could play in their country of origin.

After the Second World War the new Italian Constitution approved in 1948 granted all Italian citizens equal rights and protections under the law and granted suffrage to all adult men and women over the age of eighteen for voting in members of the Chamber of Deputies, and men and women over the age of twenty-five for the Senate. The new constitution rekindled the debate over the rights of Italian citizens abroad. Since all citizens are equal under the law, dual citizens who live abroad should have the same rights of citizens living in Italy, including the right to vote. According to the law, Italian citizens 
abroad in order to vote were required to return to Italy to vote and vote as members of their local town/comune of origin. ${ }^{18}$ This presented three problems: 1) the expense and inconvenience of returning to Italy prevented most Italians abroad from voting and 2) Italian emigrants living abroad equaled or outnumbered the actual number of current residents in many small local districts; and lastly 3) the needs and concerns of Italians outside of Italy were different from those of the their ancestral communities in Italy.

\section{The Making of an Italian Constituency Abroad}

Recently, many Italian emigrants and their children have taken advantage of an Italian citizenship law from the early twentieth century which stated that any individual who could show a direct line of blood descent from an Italian citizen who did not renounce his citizenship inherited Italian citizenship and could petition to have it recognized by providing proper documentation. These documents include birth, marriage, and death certificates for parents, grandparents, and great-grandparents. Citizenship by descent can be demonstrated through a paternal link or maternal link if after 1948. ${ }^{19}$

Earlier in the century few if any Italian immigrants had applied to have the Italian citizenship of their children recognized, but as Italy prospered economically many Italian emigrants and their children especially those living in Latin America took advantage of the existing law. Changes in national laws over the past thirty years allowing for dual citizenship along with European integration and socio-economic change in Italy and abroad has made the idea of attaining Italian citizenship more attractive than ever before. Many of these emigrants and their children have now obtained dual citizenship, established new links with Italy and lobbied for a greater voice in Italian politics making the issue of the vote abroad especially pressing.

In 2001 during the economic crisis that gripped Argen- 
tina, thousands lined up with applications in hand around the Italian Embassy in downtown Buenos Aires hoping to take advantage of the Italian citizenship law. Skeptical Italian commentators at the time were suspicious of the motivation behind those Argentine applicants who had conveniently rediscovered their Italian identity in the midst of an acute economic recession and rising unemployment. Whatever their motivations may have been, these newly recognized Italian citizens chose to identify with the nation of their ancestors and were once again able to participate fully in Italy's national life. Though they had no way of knowing it at the time, they soon played an important part in Italian national politics.

\section{The New Law Granting Italians Abroad the Vote}

On December 27, 2001 Italian Parliament ratified law number 459 recognizing the right to vote for Italians living abroad as well as granting Italians abroad the right to elect their own deputies to Italian Parliament. ${ }^{20}$ The law provided a structure for mail-in voting for all Italian citizens abroad registered through AIRE (Anagrafe degli Italiani Residenti all'Estero). Italians abroad were given twelve seats in the Chamber of Deputies (out of 630) and six seats in the Italian Senate (out of 315) representing the "Foreign Constituency." This constituency was divided into four parts: Europe; North and Central America; South America; and Africa, Asia, Oceania, and Antarctica. The seats were apportioned in the following way: Europe with 2,072,410 Italian Citizens Abroad was given six seats in the Chamber and two in the Senate; South America with 1,017,776 Italians was given three seats in Chamber and two in the Senate, North and Central America with 359,852 Italians was given two seats in the Chamber and one in the Senate, and Africa-Asia-Oceania-Antarctica with 199,339 was given one seat in each house. The number of Italian Citizens Abroad totaled 3, 649, 377. ${ }^{21}$ With the passage of this law Italy became one of a select few nations which have allotted separate specially des- 
ignated seats in parliament for its citizens abroad, other nations include France, Portugal and Colombia. ${ }^{22}$

Mirko Tremaglia a member of Gianfranco Fini's Alleanza Nazionale the right-wing successor to the fascist party, was the architect of the new law. Tremaglia had an ulterior political motive for promoting the new law. He assumed that the inclusion of Italians abroad with its appeal to Italian nationalist sentiments would deliver more votes to the right. On the eve of the 2006 election Silvio Berlusconi's center-right coalition anticipated a boost from the vote abroad. The election in April produced the exact opposite result. Italians abroad voted overwhelmingly for Romano Prodi's center-left coalition. It was a devastating blow to the Right since these votes from abroad were what tipped the balance in one of the closest elections in Italian history. The political significance of the vote from abroad renewed concerns over the question of Italian citizenship abroad.

\section{The New Law and Its Implications on Identity and Belonging}

The importance of the vote abroad in determining the election magnified a number of troubling implications of the debate over the new law. A recent scandal just this past year has heightened criticism over the law. One of the Italian Senators Abroad, Nicola Di Girolamo was removed from office after widespread voter fraud and corruption was uncovered. While some political commentators used this as an excuse to question the honesty of the Italian vote abroad it has led others to call for reforming the voting process rather than repealing the law. According to the prominent Italian journalist Sergio Romano the very nature of the vote abroad lent itself to this fraud. In a recent editorial for Corriere della Sera he writes, "the law does not interest the majority of Italian emigrant communities, especially those outside of Europe and there is a close connection between this lack of interest and fraud." 23 Defenders of the new law were 
quick to point out that fraud is just as prevalent in election results within Italy, as the Secretary General of Italians Abroad insisted, such isolated cases of election fraud "have never cast doubt on the legitimacy of the right to vote within Italy and should not serve as an alibi to call into question the vote abroad." 24

The concern over the integrity of voting outside of the nation's supervision speaks to the broader issue of the foreign context of the vote and the influence of foreign governments and local interests in the election. The Argentine election experience is a case in point. Counting 496, 000 Italian citizens, Argentina had the second largest number of Italians living abroad behind only Germany. ${ }^{25}$ On the surface, the case of Italian Argentine participation in Italy's recent elections is evidence that Italian identity has persisted in Argentina into the twenty-first century. But the question of these Italian Argentines' national identity is still more complex. While I was in Buenos Aires just after the election of 2006 I had the opportunity to speak with an international news correspondent who had followed the Italian vote in Argentina. He suggested that one of the reasons why Prodi had won so many votes in Argentina was thanks to Néstor Kirchner, Argentina's left-wing president, who used his own political machine to support Prodi's campaign and mobilize the vote. In addition to supporting a fellow traveler on the Left, Kirchner had a concrete interest in supporting the left-center economist since Prodi's economic platform was favorable to Argentine interest. This suggests that the Italians in Argentina in deciding how to vote were influenced as much by Argentina's national politics as by Italian politics and indicates a much more intricate relationship between these individuals and the two nations with which they have chosen to identify.

Another concern that has been raised is over the influence residents living outside of the national territory should have in national elections. Although some citizens abroad have relatives still living in Italy and/or own prop- 
erty and pay taxes, many do not. This has led some Italians, both in Italy as well as abroad, to question the new laws validity. ${ }^{26}$ As Romano again writes "those who maintained their citizenship should enjoy the right to vote not those who have been bestowed that right because they have an Italian grandfather and have even forgotten the language."27 This criticism is not entirely fair, since citizens abroad who went through the trouble of having their citizenship recognized have voluntarily demonstrated their loyalty to Italy and their interest in the nation's well-being. Furthermore, many Italians living abroad have spent years studying the Italian language and culture from abroad, and can at times be even more well informed than many of their compatriots within Italy. In fact, the effort involved in registering to vote abroad demonstrates an interest in Italian politics that all but ensures their making an informed choice. ${ }^{28}$

While Italy has a relatively open policy towards its emigrant compatriots who have had their citizenship recognized, it has much more stringent naturalization policies towards its new immigrant residents. Over the past thirty years Italy has gone from a nation of emigrants to a nation of immigrants. Millions of immigrants from Africa, Eastern Europe, Latin America and Asia are arriving in Italy today. An adult non-European Union national must reside in Italy for a minimum of ten years before they can apply for citizenship and children of immigrants born in Italy have to wait until their eighteenth birthday before they can attain Italian citizenship. ${ }^{29}$ This raises the question of who therefore is more deserving of citizenship, those residents directly impacted by Italian laws making direct contributions in terms of labor, consumption, and taxes to the Italian nation or Italian citizens abroad, who may be ethnically Italian but may or may not be affected directly by Italian government policies. ${ }^{30}$

In this regard, the Italian government's position most closely fits with Bauböck's concept of an ethnic nationalist citizenship which supports voting rights for citizen 
expatriates but opposes those rights for non-citizen residents. As Bauböck explains, "It conceives of the nation as a community of culture, imagined descent, and destiny that has a right to self-determination ...It is therefore imperative to include external citizens in national selfgovernment and legitimate to exclude non-citizens who have not assimilated into the national community."31

While the Italian experience is relatively new, the case of France demonstrates the disparity between citizenship and belonging. Algerians and West Africans are able to attain full French legal citizenship but have faced a tremendous amount of prejudice and racism and have difficultly integrating themselves fully into the French nation. ${ }^{32}$ Even after generations of living in Italy it is unlikely non-European Italian citizens will ever be fully accepted as Italian. New racial tensions have arisen in Italy sparked by the recent influx of non-European migrants which many see as a threat to Italy's national and cultural identity as a nation. Even once attaining legal citizenship these new immigrants and their children will have a difficult time being fully accepted as Italian. ${ }^{33}$ Many Italian citizens abroad are similarly viewed skeptically as outsiders or "fake" Italians, a term I have heard often in discussing the vote and citizenship abroad in Italy. These objections and concerns raised by Italians both at home and abroad are a reflection of an alternative citizenship argument discussed by Bauböck which supports voting rights for residents but questions those of citizens abroad, who "should not be able to influence the making of laws to which only internal residents will be subjected."34

In both the cases of immigrants in Italy as well as Italians abroad these assumptions do not seem well founded. Immigrants who live and work for years in Italy share the experiences of their fellow native Italian residents, while many Italians abroad in addition to sharing a common cultural heritage have in fact maintained or re-established connections with their ancestral homeland. Both populations therefore have to a greater or lesser degree 
something similar to what Bauböck has defined as "stakeholdership," whether it be material in the case of the immigrants or cultural in the case of the emigrants.

The participation of Italians abroad in both the voting process as well as in the ensuing debates it inspired also confirms Bloemraad's assertion that rather than weakening the traditional nation-state, transnational citizenships can actually reinforce its relevance in the world today. This experience, however, also leads us to question the importance we instinctively place on geographical space in delimiting the nation since a citizen's physical presence within the nation-state is not required to be actively engaged in its political life. It is a fascinating point that the Italian State has been quick to embrace.

In welcoming Italians abroad to the Italian Parliament's website the President of the Chamber of Deputies, Gianfranco Fini writes "You already know that the internet is an important instrument, because it allows you to establish a solid, continuous and immediate contact with the Republic's institutions. It is a more modern, more efficient way to be closer to Italy." 35 His comments allude to an intriguing aspect of the issue of the Italian vote abroad: The role of new technology and media in connecting Italians abroad to the nation. With the internet, satellite television, world phones, podcasts, etc. it is now possible for Italians abroad to not only be informed but to be to be immersed in Italian politics and culture. ${ }^{36}$

In nations such as Argentina the Italian state-sponsored RAl television network is broadcasted throughout the day in Italian, and Italian products and advertizing are a common sight in Buenos Aires. Italians living in Argentina would have been able to read Sergio Romano's editorial questioning their knowledge of Italy and the Italian language both in print from any local newsstand or online. In fact in today's digital age it is possible to be an even more actively involved and informed citizen than many of the citizens living within the Italian state. Furthermore the relative ease and low cost of travel and in- 
ternational financial transactions has made it possible for citizens abroad to be contribute significantly to the Italian economy. These global innovations therefore make it theoretically possible for an Italian citizen who has never resided in Italy to be as well informed and to have as much a stake in the Italian political process as someone living within Italy.

\section{The Italian Case in a Comparative Perspective}

Italy's new law and the issues it entails is an especially relevant model for the nations of Latin America today. Many of these nations' migration patterns mirrored the Italian historical migration experience. Latin American migrants today are leading even more transnational lives than the Italian emigrants of the past. As more and more Latin Americans migrate to the United States and Europe, attain dual citizenship, send remittances back to their home country, and establish business and familial links across borders Latin American governments are now faced with the same constitutional dilemma faced by Italians. ${ }^{37}$ This is especially true in nations with large numbers of emigrants who have made significant financial contributions to home countries economy, not to mention the cultural impact they have had through the transfer of consumer goods and return travel. The political role these citizens abroad could play through voting abroad is therefore potentially even more impactful than the Italian case has already proven to be. ${ }^{38}$

Proportionally as well as financially the number of citizens abroad in some nations is even more significant than those of the Italian case, making their impact that much more important. In a small nation like El Salvador, with over 25 percent of the population emigrating, remittances from relatives living in the United States is actually the leading source of export earnings and over 16 percent of the nation's gross domestic product. ${ }^{39}$ Just as the Italian liberal regime had done over one hundred years ago, the government of $\mathrm{El} \mathrm{Salvador}$ has created 
state agencies to preserve and foster links with its community abroad. The Salvadoran Dirección General de Atención a las Comunidades en el Exterior bears a striking resemblance in its functions to Italy's Commissariato Generale dell'Emigrazione by providing its emigrants with legal and social counseling and information services. El Salvador's Foreign Ministry is also advocating for the rights of its citizens abroad as well as reaching out to its communities in much the same way as Italian governments in the past. ${ }^{40}$

The Philippines represent another fascinating comparison to the Italian case. Similar to El Salvador, the Philippine government takes an active interest in its citizens abroad. Since the 1970s it has in fact not only promoted emigration but actually brokered overseas labor arrangements, providing institutional training, support and research for its migrant workers. ${ }^{41}$ Robyn Rodriguez in her recent work, Migrants for Export: How the Philippine State Brokers Labor with the World (2010), argues that this labor export apparatus has redefined notions of citizenship in the Philippines. According to Rodriguez, these migrants, far from being considered less worthy of citizenship, are actually exalted as national heroes and are expected to fulfill their obligations of citizenship by sending home remittances to support the national economy and returning home at the end of their labor contracts. For this process to work, maintaining linkages with the home country and instilling patriotism in its emigrants is essential. ${ }^{42}$

The Philippine and Salvadoran cases are both modern manifestations of many of the processes which historically have affected the debate on Italian citizenship abroad. In both instances we see attempts by the nation-state to create an extraterritorial citizenry who remained actively engaged in the welfare of their nation of origin. As Salvadoran emigrants and Philippine migrants become more and more involved politically, it will be interesting to see how the citizenship question and the debates it 
engenders play out making Italy an especially relevant point of reference.

\section{Conclusion}

The debate over the Italian vote abroad questions traditional models of citizenship and points towards a new transnational model. Given our new interconnected world and the new needs of the individual citizen and the nation-state we need to re-examine exactly how we define citizenship and ask ourselves what ties an individual to a nation and who should be given a right participate in that nation's political process. Furthermore, we must ask who are impacted more by a nation's laws? Are those citizens living within the nation necessarily more impacted than those living abroad?

As this article has demonstrated, the question of Italian citizenship abroad has deep roots in Italian history. The recent Italian law granting its citizens abroad the right to elect their own representatives to Parliament is however not only the culmination of a long developing historical process, it is also one of many new responses that have to be considered in order to adapt traditional models of citizenship to the realities of a new globalized world. As such, it serves as an important model which highlights many of the problems and limits to transnational approaches to citizenship today. While the debate will continue over the merits of the new law, there is no doubt that it has already played an important role in changing the way we define citizenship and belonging in the twenty-first century.

\section{Notes}

1 Donna Gabaccia, "Is Everywhere Nowhere? Nomads, Nations, and The Immigrant Paradigm of United States History," The Journal of American History (December, 1999).

2 Irene Bloemraad, "Who Claims Dual Citizenship? The Limits of Postnationalism, the Possibilities of Transnationalism, and the Persistence of Traditional Citizenship," International 
Migration Review, (Vol. 38, No. 2, 2004), pp 420-422.

3 Rainer Bauböck, "Expansive Citizenship-Voting beyond Territory and Membership," Political Science and Politics, Vol. 38.

No. 4 (October , 2005).

4 Donna Gabaccia, Italy's Many Diasporas (Seattle: University of Washington Press, 2000), 9, 11.

5 Mark I. Choate, Emigrant Nation: The Making of Italy Abroad (Cambridge: Harvard University Press, 2008), 18.

6 Commissariato Generale dell'Emigrazione, Il Bollettino dell'Emigrazione, 1922-1927.

7 David Aliano "Brazil through Italian Eyes: The Debate over Emigration to São Paulo during the 1920s," Altreitalie, Number 31, July-December 2005. São Paulo (Estado) Mensagem apresentada ao Congreso Legislativo em 14 de Julho pelo Washington Luis Pereira de Sousa, 1922, 50.

8 Italian Consulate records for New York City housed in the Farnesina Historical Archive in Rome.

9 Emilio Gentile, “'L'Emigrazione italiana in Argentina nella politica di espansione del nazionalismo e del fascismo" in Storia Contemporanea, 17 (3), 1986, 355-396.

10 Benito Mussolini, "Per il Consiglio Superiore dell'Emigrazione," 245, 1923, Opera Omnia di Benito Mussolini, a cura di E. e

D. Susmel, vol.XIX Firenze: La Fenice, 1957.

11 Conférence Internationale de l'Emigration et de l'Immigration= Rome 15-13 Mai 1924. Travaux de la Conférence. Rome:

Commissariat General Italien de L'Emigration.

12 Conférence Internationale de l'Emigration et de l'Immigration= Rome 13-15 Mai 1924 Acte Finale, (Rome : Commissariat General Italien de L'Emigration, 1924); Aliano, 103-104.

13 Ibid.

14 Ibid.

15 Gentile, 355-396.

16 Dino Grandi, "Discorso alla Camera dei Deputati," March 31, 1927, in La politca estera dell'Italia dal 1929 al 1932, Paolo Nello ed., (Roma: bonacci Editore, 1985) 132.

17 Piero Parini, Gli italiani nel mondo, ( Roma: Fasci all'Estero, 1935).

18 Camera dei Deputati, Manuale Elettorale: Il Voto degli Italiani all'Estero (March 18,2008).

19 Italian Consulate General of New York, Information kit on Italian Citizenship Jure Sanguinis.

20 Legge 27 dicembre 2001, n. 459 "Norme per l' esercizio del diritto di voto dei cittadini italiani residenti all' estero," published in the Gazzetta Ufficiale n. 4, January 5, 2002. 
21 Camera dei Deputati, Manuale Elettorale: Il Voto degli Italiani all'Estero, March 18,2008.

22 Bauböck, (2005), 683.

23 Sergio Romano, "Il voto italiano all'estero una legge da cambiare" Corriere della Sera, March 5, 2010.

24 “Italiani all'Estero-Di Girolamo-Voto All'Estero," from www. italiannetwork.it, March 1, 2010.

25 La Repubblica, December 20, 2001.

26 Elisa Arcioni, "Representation for the Italian Diaspora" Democratic Audit for Australia, December, 2006, 1-8.

27 Romano, op. cit.

28 Rainer Bauböck, "Towards a Political Theory of Migrant

Transnationalism," International Migration Review, Vol. 37, No. 3, (Fall, 2003) pp 700-723.

29 Arcioni, op. cit.

30 Ibid.

31 Bauböck, (2005), 683-686.

32 Paul A. Silverstein, Paul A, "Kabyle Immigrant Politics and Racialized Citizenship in France," in Citizenship, Political Engagement, and Belonging, (New Brunswick: Rutgers University Press, 2008) 23-42.

33 Flavia Stanley, "On Belonging in/to Italy and Europe" in Citizenship, Political Engagement, and Belonging, (Rutgers University Press, New Brunswick, 2008) 43-59.

34 Bauböck, (2005), op. cit.

35 Gianfranco Fini, "Messaggio di benvenuto del Presidente della Camera," www.camera.it/_votoitaliani/.

36 Bauböck, (2003), 714.

37 Cristina Escobar, "Extraterritorial Political rights and Dual Citizenship in Latin America," Latin American Research Review, Vol. 42 No. 3, October 2007.

38 Escobar's article (op. cit.) provides an excellent comparative analysis of voting and extraterritorial citizenship in Latin American today.

39 Sarah Gammage, "Exporting People and Recruiting Remittances, A Developmental Strategy for El Salvador?" Latin American Perspectives, Issue 151, Vol. 33 No. 6 (November, 2006) 75.

40 Gammage, 89-92.

41 Robyn Magalit Rodriguez, Migrants for Export: How the Philippine State Brokers Labor to the World (Minneapolis: University of Minnesota Press, 2010).

42 Rodriguez: 2010, 92. 


\section{Works Cited}

Aliano, David. 2005. “Brazil through Italian Eyes: The Debate over Emigration to São Paulo during the 1920s, "Altreitalie, Number 31, July-December 2005.

Arcioni, Elisa. 2006. "Representation for the Italian Diaspora" Democratic Audit for Australia.

Bauböck, Rainer. 2005. “Expansive Citizenship-Voting beyond Territory and Membership, "Political Science and Politics, Vol. 38. No. 4.

---. 2003. "Towards a Political Theory of Migrant Transnationalism," International Migration Review, Vol. 37, No. 3. pp 700-723.

Bloemraad, Irene. 2004. “Who Claims Dual Citizenship? The Limits of Postnationalism, the Possibilities of Transnationalism, and the Persistence of Traditional Citizenship," International Migration Review, Vol. 38, No. 2, pp 389-425.

Bollettino dell'Emigrazione. 1922-1927. Rome: Commissariato Generale Dell'Emigrazione.

Camera dei Deputati. 2008. Manuale Elettorale: II Voto degli Italiani all'Estero. Rome: Camera dei Deputati.

Choate, Mark I. 2008. Emigrant Nation: The Making of Italy Abroad, Cambridge: Harvard University Press.

Commissariato Generale dell'Emigrazione. 1926. Manuale di Geografia economica di legislazione sociale e di notizie utile per gli Italiani all'estero. Rome: Commissariato Generale dell'Emigrazione. 
Conférence Internationale de l'Emigration et de l'Immigration= Rome 15-13 Mai 1924. Travaux de la Conférence. Rome: Commissariat General Italien de L'Emigration.

--- 1924. Acte Finale. Rome: Commissariat General Italien de L'Emigration.

Consolato Generale D'Italia. 2007. Information kit on Italian Citizenship “Jure Sanguinis," New York: Italian Consulate General.

Escobar, Cristina. 2007. “Extraterritorial Political rights and Dual Citizenship in Latin America," Latin American Research Review, Vol. 42. No. 3.

Fini, Gianfranco. 2010. "Messaggio di benvenuto del Presidente della Camera." www.camera.it/_votoitaliani/.

Gabaccia, Donna. 2000. Italy's Many Diasporas. Seattle: University of Washington Press.

-.-. 1999 “Is Everywhere Nowhere? Nomads, Nations, and The Immigrant Paradigm of United States History," The Journal of American History (December, 1999).

Gammage, Sarah. 2006. “Exproting People and Recruiting Remittances: A Developmental Strategy for El Salvador?" Latin American Perspectives, Issue 151, Vol. 33., no. 6, November 2006, 75-100.

Gentile, Emilio. 1986. “'L'Emigrazione italiana in Argentina nella politica di Espansione del nazionalismo e del fascismo" in Storia Contemporanea, 17 (3) 355-396. 
Grandi, Dino. 1927. "Discorso alla Camera dei Deputati," in La politca estera dell'Italia dal 1929 al 1932, Paolo Nello ed., Roma: bonacci Editore, 1985.

Italian Network. March 1, 2010. "Italiani all'Estero-Di Girolamo-Voto All’Estero." www.italiannetwork.it.

Legge 27 dicembre 2001, n. 459. 2002. "Norme per l' esercizio del diritto di voto dei cittadini italiani residenti all'estero." Rome: Gazzetta Ufficiale n. 4.

Mussolini, Benito. 1923. "Per il Consiglio Superiore dell'Emigrazione" Opera Omnia di Benito Mussolini, a cura di E. e D. Susmel, Firenze: La Fenice, 1957.

Piero Parini. 1935. Gli italiani nel mondo, Roma: Fasci all'Estero. La Repubblica. December 20, 2001.

Rodríguez, Robyn Magalit. 2010. Migrants for Export: How the Philippine State Brokers Labor to the World. Minneapolis: University of Minnesota Press.

Romano, Sergio. March 5, 2010. "Il voto italiano all'estero una legge da cambiare" Corriere della Sera.

São Paulo (Estado), Brazil. 1922. Mensagem apresentada ao Congreso Legislativo em 14 de Julho pelo Washington Luis Pereira de Sousa.

Silverstein, Paul A. 2008. "Kabyle Immigrant Politics and Racialized Citizenship In France, " in Citizenship, Political Engagement, and Belonging. New Brunswick: Rutgers University Press. 
Ethnic Studies Review Volume 33.1

Stanley, Flavia. 2008. "On Belonging in/to Italy and Europe" in Citizenship, Political Engagement, and Belonging. New Brunswick: Rutgers University Press. 